Ana Dili Eğitimi Dergisi
Journal of Mother Tongue Education
ADED - JOMTE
www.anadiliegitimi.com

\title{
Türkçe Dersi Metin İşleme Sürecinde Bağlam Temelli Sözcük Öğretimi ve Etkin Sözcük Dağarcığı Oluşturmadaki İşlevi * \\ Ali GÖÇER $R^{* *}$ \\ Özet
}

Bu çalışmanın amacı, metin işleme sürecinde sözcük öğretiminin bağlam temelli gerçekleştirilmesi ve bu uygulamanın, öğrencilerin aktif sözcük dağarcı̆ını geliştirmedeki önemini vurgulamaktır. Sözcük varlığı, bireyin anlama ve anlatma becerisini etkin bir şekilde sergileyebilmesinde en temel belirleyici unsurdur. Bu çalışmada metin işleme sürecinde öğrencilerin ilk ez karşılaştıkları veya anlamı bağlamdan çıkarılamayan sözcüklerin öğretilmesinde öğrencilerin merkeze alındığı ve sözcüğün yapı içerisinde üstlendiği işlevlerin ön planda tutulduğu bağlam temelli sözcük öğretimi çalışmaları üzerinde durulmuştur. Bu çerçevede, öncelikle literatür taraması yapılarak konunun alanyazındaki durumu ile ilgili genel bir görünüm oluşturulmuştur. İlgili alanyazından elde edilen veriler yanında, kişisel görüş ve değerlendirmelerle metne son şekli verilmiştir. Bu çerçevede, bağlam temelli sözcük öğretiminin, öğrencilerin etkin/işlek sözcük dağarcığını geliştirmelerine önemli katkı sağlayabileceği vurgulanmıştır. Ayrıca, bağlam temelli sözcük öğretimi yapılmasının yararlarına değinilerek öğretmenlere, metin işleme sürecindeki sözcük öğretimi çalışmalarını bu anlayışla gerçekleştirmeleri önerilmiştir.

Anahtar Kelimeler: Metin işleme süreci, sözcük öğretimi, anlama ve öğrenme.

\section{Function of Creating an Effective Vocabulary and Importance of Context Based Vocabulary Teaching in Turkish Language Text-Handling Process}

\begin{abstract}
The aim of this study is to emphasize the importance of education to be based on the context of the word in the text processing of students active in the development of vocabulary. The presence of the word is the main determinant of the ability of the individual to understand and explain the exhibits effectively. This study focused on studies in teaching vocabulary text processing in the first crush faced by students are not learning from the context and word-based context is kept in the forefront of the function assumed in the structure. In this context was created primarily an overview of issues related to the situation in the literature review the literature. In addition to the data obtained from the relevant literature is finalized to the text with personal opinions and evaluations. Thus, the context-based teaching vocabulary is emphasized that important contributions to develop the students active/ common use vocabulary. In addition, making reference to the context of the benefits of word-based teaching was recommended to the teachers teaching words in the text-processing work to perform this technique.
\end{abstract}

Keywords: Text processing, vocabulary, understanding and learning.

\footnotetext{
* 30-31 Ekim 2014 tarihlerinde Türk Dil Kurumu ve Cumhuriyet Üniversitesi tarafından ortaklaşa düzenlenen Anadili Olarak Türkçenin Eğitimi ve Öğretimi Çalışma Toplantısı'nda sunulan bildiri temel alınarak oluşturulmuştur.

** Doç. Dr., Erciyes Üniversitesi, Eğitim Fakültesi, Türkçe Eğitimi Bölümü. e-posta: ali.gocer@hotmail.com
} 


\section{Türkçe Dersi Metin İşleme Sürecinde Bağlam Temelli Sözcük Öğretimi ve Etkin Sözcük Dağarcığı Oluşturmadaki İşlevi}

\section{Giriş}

Dil, insanların meramlarını anlatmak için kullandıkları bir sesli işaretler sistemidir (Banguoğlu, 1986, s. 10). Bu işaret sistemi zaman içerisinde olgunlaşarak belli bir düzene ulaşmış, belli bir sistematiğe kavuşmuştur. Oluşan sistematik içerisinde sesleri karşılayan harfler bulunarak alfabeler oluşturulmuştur. Seslerin ağızdan bir bütünleri olan heceler ile hecelerden oluşarak anlam yüklenen ses toplulukları olan sözcükler, dilin sistematiğini gösteren temel göstergelerdir. Günay’a göre, sözcük bir dilin temel ögesidir. Bir dilin zengin ya da fakir olmasını sözcükle değerlendirenler çoktur (2007b, s. 11). Üçok'a (1947) göre de dilin en küçük birliği kelimedir. Kelime, ağzımızdan çıkan ses kompleksinin zihnimizde kavrama ait mana ile birleşmesinden meydana gelen bir işaret, bir semboldür (s. 5). Bir kelimeyi ses, şekil, görünüş, telaffuz ve çeşitli ipuçlarından tanıma, yazılı olarak görünce hatırlama, anlamını bulma ve seslendirme kelime tanıma olarak açıklanmaktadır (Güneş, 2013, s. 229). Bununla birlikte kelimenin genel geçer bir tanımını yapmak güçtür. Çünkü her dilin kendine özgü bir yapısı vardır ve yapısal özelliklere göre kelime tanımı da değişebilmektedir. Her kelimenin iki türlü manası vardır. Biri cümle içinde, öteki cümle dışında başlı başına olduğu zamanlardaki manasıdır. Kelimelerin esas manaları cümle içinde aldıkları ve yanlarındaki kelimelere göre değişen manalardır (Üçok, 1947, s. 85). Dilbilim terminolojisinde buna 'anlam değeri' adı verilmektedir. Bu konuda Onan (2011) şunları ifade etmektedir: Okuma ve dinleme beceri alanlarındaki kazanımların semantik yapıdan yararlanılarak geliştirilmesinde, öğrencilerin pasif kelime hazinelerindeki unsurların, sözcük anlamı, çağrışımsal anlam ve bağlamsal anlam düzeyinde geliştirilmesi gerekmektedir. Bu açıdan özellikle çağrışımsal ve bağlamsal anlam değerleri önemlidir (s. 430).

Dili etkili, güzel ve doğru bir biçimde kullanabilmede bireyin sahip olduğu kelime hazinesinin önemi büyüktür (Göçer, 2009, s. 1026). İnsan hayatında etkin role sahip unsurlardan biri olan dilin vazgeçilmezliğinin temelinde, insanoğluna kendisini ve dış dünyayı ifade etmesinde yardımcı olan sözcükler yatmaktadır. Sözcükler, insan zihninin isteğe bağlı olarak ürettiği yapay göstergelerdir. İnsanoğlu bu yapay göstergeler sayesinde dış dünyanın ayrıştırılarak içselleştirilmesini, algılanmasını ve anlamlandırılmasını gerçekleştirebilmektedir (Yalçın ve Özek, 2006, s. 130-131).

Yazınsal metinler, alıcıya bir şey esinleme ve onda bir şey çağrıştırma gücüne sahiptir. Bir metnin anlamı, bir okuyucuya ya da bir izleyiciye göre vardır. O hâlde, metnin anlamı yoruma açıktır. Her metnin kendi bağlamı içinde taşıdığı anlam, okur tarafından değişik biçimde yorumlanmalıdır.

Yazınsal yapıtların okunmasıyla ulaşılabilecek pek çok kazanım vardır. Bunlardan bazıları şöyle belirtilebilir: Mantıklı düşünme, açıklama biçimlerini geliştirme, çözümleme ve bireşim yeteneği kazanma, bir metni eleştirebilme yetisini kazanma, aynı durumu ya da olayı farklı yorumlayabilmek için akıl yürütme yetisini kazanma, sezgisel düşünme yeteneğini kazanma, okunan ve dinlenen bir metinde 
önemli olanı önemsiz olandan ayırabilme, imgeleme ve sezgisel düşünebilme yeteneği kazanma... (Günay, 2007a, s. 17). Bütün bu ve benzer kazanımlara sahip olabilmede bireyin sözcük dağarcığının önemi büyüktür.

Öğrencileri bir üst eğitim kurumuna, daha da önemlisi hayata hazırlama işlevini gören okullarımızda verilen eğitimin niteliği, genelde öğrencilerin temel dil becerilerini kazanarak etkin bir biçimde kullanabilir olmalarına, özelde ise, bu becerileri etkin kılan aktif kelime dağarcığının zenginliğiyle ortaya çıkmaktadır. O hâlde öğrencilerin kelime dağarcıklarının zenginleştirilmesi ve öğrenme - öğretme sürecinde kelime öğretimi uygulamaları büyük önem arz etmektedir (Göçer, 2009, s. 1029). Bu açıdan okullarımızda Türkçe ve sınıf öğretmenleri Türkçe dersi metin işleme sürçlerinde kelime öğretimi çalışmalarını bilinçli ve özenli bir şekilde yürütmelidirler.

\section{Sözcük Dağarcığı ve Önemi}

Bir kişinin kazandığı sözcüklerin hepsine sözcük dağarcığı denir. Sözcük dağarcığı işleyiş yönünden iki türlü canlıık gösterir. 1. Konuşurken, yazarken kullanılan etkin (aktif) sözcükler. 2. Dinlerken, okurken anlaşılan edilgin (pasif) sözcükler. Etkin sözcüklerin sayısı, edilginlere göre çok azdır. Çünkü, insanlar dinleyerek, okuyarak, görerek birçok konu üzerinde sözcükler öğreniyorlarsa da bunlardan ancak uğraşıları ve ilgileri üzerindeki sözcükleri kullanmaktadırlar (Göğüş, 1978, s. 360-361).

Sözcük dağarcığı, bir bireyin zihninde yer bulan sözcüklerin tamamı; aktif sözcük dağarcı̆̆ı ise, günlük yaşamında duygu, düşünce ve isteklerini dile getirirken kullandığı sözcük kadrosudur. Bu bakımdan sahip olunan sözcük dağarcığı, bireyin eğitim hayatında, sosyal yaşamında, karşılaştığı sorunları çözebilmesinden çevresindekilerle iletişimine kadar yaşam kalitesini etkileyen önemli bir unsurdur. Bireyin yaşamında bu çerçevede yer bulan, hayatın her aşamasında belirleyici bir işlev gören sözcük dağarcığının zenginleştirilmesi de büyük önem taşımaktadır. Öğrencilerin dil yeterliklerinin geliştirilmesine, sözcük dağarcığının zenginleştirilmesine Türkçe eğitimi uygulamalarında yer verilmektedir.

Yazılı ve sözlü anlatımda rahatça kullanabildiğimiz kelimeler aktif, ara sıra duyduğumuz ve bir metin içinde karşılaştığımız zaman anladığımız kelimeler ise pasiftir. Bildiğimiz kelimeler, kullandığımız kelimelerden daha fazladır. Aktif kelime kullanılan, pasif kelime ise, bilinendir. Aktif kelime kadrosunun zenginliği, hem okunanı, duyulanı kolay ve doğru anlamayı hem de anlatımı kolaylaştııı (Karakuş, 2000, s. 128). Bireylerin aktif sözcük dağarcığının zengin olması önemlidir. Bu bakımdan okullarda özellikle de Türkçe eğitimi içerisinde metin işleme süreçlerinde söz varlığını geliştirme etkinliklerini amaçlı ve bilinçli gerçekleştirmek gerekir. Genç'in (2010) yaptığı bir araştırma sonucuna göre, öğrencilerin yeni öğrendikleri kelimeleri kullanım durumları oldukça düşüktür (Akt.: Başoğlu, Kaplan ve Okur, 2014, s. 


\section{Türkçe Dersi Metin İşleme Sürecinde Bağlam Temelli Sözcük Öğretimi ve Etkin Sözcük Dağarcığı Oluşturmadaki İşlevi}

58). Bu bakımdan metin işleme süreci sonunda yaptırılacak bütünleyici çalışmalarla öğrencilerin öğrendikleri yeni kelimelerin kullanıldığı yazılı anlatım çalışmalarının gerçekleştirilmesi, kalıcı ve kullanılabilir öğrenmeleri sağladığından aktif sözcük dağarcı̆ııın gelişimi açısından önemli işlev görebilir. Göğüş'e (1978) göre, sözcük bilgileri başka bilgilere benzemez, birbirini tamamlamaz, birbirinden ayrı ve kopuktur. Bu nedenle, sözcükler üzerindeki bilgilerin zaman zaman yinelenmesi gerekir (s. 369). Bunun en etkili yolu da sözcük bilgisinin okuma, konuşma ve yazma çalışmaları çerçevesinde kelimelerin anlam değerleri çerçevesinde etkinlikler gerçekleştirilerek bir becerinin işlevselliğine farklı açılardan katkı veren bir araç olarak kullanmadır. Bu şekilde sözcükler aktifleşir ve daha geniş bir anlam değerinde ya da yelpazesinde kullanılabilirlik kazanabilir.

Türkçe öğretiminde temel dil becerilerinin kazandırılması hedeflenmekte ancak, bu becerilerin kazandırılabilmesi için öncelikle bazı ön koşul edinim ve öğrenmelere ihtiyaç duyulmaktadır. Bunların birisi de öğrencilerin kelime bilgisinin geliştirilmesidir (Budak, 2000). David H. Russel, sözcük bilgisini üç boyutta tanımlar: 1. derinlik (sözcüklerin çeşitli anlamlarını bilmek ve duruca anlamak); 2. genişlik (çeşitli konularda sözcükler bilmek), 3. ağırlık (bir konuda çok sözcük bilmek). Bu boyutlar, çocuklar büyüdükçe, yetişme yoluna göre ilerleyip genişler (Akt.: Göğüş, 1978, s. 360).

Sözcük ve sözcük öbeklerinin öğretimi anadili öğretiminin en önemli çalışmalarından biridir. Çünkü okuma, yazma, konuşma ve dinleme olarak belirtilen dört dilsel becerinin kazandırılması ile sözcük dağarcığı arasında sıkı bir ilişki vardır. Öğrencilerin okuduklarını ve dinlediklerini anlamaları, sözcükleri doğru anlamlandırmalarına bağlıdır (Pehlivan, 2003, s. 84). Sözcük öğretimi, anadili eğitimi sisteminin önemli bir parçasıdır ve dört temel dil becerisinin gelişimine katkıda bulunmaktadır. Daha doğru ve iyi anlayan, anlatan bireylerin yetiştirilmesi anadili eğitimini tümleyen bir süreç olarak sözcük öğretimi ile doğrudan ilişkilidir. Sözcük öğretimi, anadili eğitimi ve öğretimi sürecinde son derece önemli bir çalışma alanıdır. Öğrenciye sözcük kazandırmak üzere tasarlanacak dilbilimsel nitelik taşıyan etkinlikler sözcük öğretimine önemli katkılar sağlayabilir. Sözcük öğretimine yönelik etkinlikler, çocuğun sözvarlığını geliştirmeyi ve zenginleştirmeyi amaçlamalıdır (Mert, 2009, s. 86). Sözcük anlamlarının kalıcılığını sağlayabilme, bilginin bellekte depolanması sırasında bellek işlemlerini işlevsel hale getiren, bilginin geri çağrılmasında anımsama işleminin işlevsel olabilmesini sağlayan uygun yöntem, teknik ve ders malzemelerinin kullanıldığı sınıf içi etkinlikler gerekmektedir (Dilidüzgün, 2014, s. 238).

Etkinlikler; tanımsal bilgi (eş anlamalıları öğretmek, karşıt anlamlıları öğretmek, yakın anlamlıları öğretmek, değişmece anlamını öğretmek, öğrencilerin kendilerinin sözcüğün anlamını söylemesi/yazması, ulamlara ayırmak, biçimbilgisel özellikleri öğretmek, örnek sözcükler sağlamak, örnek olmayan sözcükler sağlamak), bağlamsal/kullanımsal bilgi (sözcüğü kendi tümcesi içinde 
kullanmak, aynı sözcüğün farklı tümcelerdeki anlamını tartışmak, sözcükle ilgili senaryo oluşturmak, sözcük/sözcüğün anlamı çerçevesinde karşılıılı konuşma yapmak, önemli konular ya da yaşantılar çerçevesinde karşılıklı konuşma yapmak) ve çoklu karşılaşma olarak sıralanabilmektedir (Ülper ve Karagül, 2012, akt.: Dilidüzgün, 2014, s. 238).

Öğrencilerin sözcük dağarcıklarını zenginleştirmek için metin işleme sürecinde sözcük öğreniminin öğrencilerin etkin olduğu amaçlı, sistemli ve bilinçli etkinliklerle gerçekleştirilmesi gerekir. Göçer'e (2009) göre, her sınıf düzeyinde yapılagelen amaçlı, sistemli ve düzenli kelime öğretimi çalışmaları, öğrencilerin bir sonraki sınıf düzeyine hazırlanmaları açısından büyük önem taşımaktadır (s. 1029).

\section{Sözcük Öğretiminde Anlam-Bağlam ilişkisi}

Sözcükbilim yakın zamana kadar dilin söz varlığına eğilen ve dildeki ögelerin kökenlerini, başlarından geçenleri inceleyen bir bilim dalı olarak tanımlanıyordu. Son yıllarda yeni gelişmeler olmuş, yapısalıılık akımının yankısı olan toplumsal sözcükbilim adlı yeni bir inceleme alanı ve yöntemi ortaya çıkmıştır. Kavram alanı ya da anlam alanı kuramından yararlanan bu yöntemde her sözcüğün kendisinin de bilindiği anlam alanı içinde ele alınması ve bu alan içinde bir değer dizgesi olarak düşünülmesi, incelenmesi (Aksan, 2007, s. 31) öne çıkmıştır. Her ne kadar, bir fikri anlatmak için 'cümle' birimi kullanılmaktaysa da 'sözcük' birimi, bir dilin 'yapı taşı' olmak niteliğini saklamaktadır. Gerçekten, sözcüksüz bir cümle olmadığı hâlde, cümlesiz bir sözcük olabilmekte ve kendi başına bir anlam taşıyabilmektedir. Ayrıca, sözcüklerin birlikte kullanılmaları da, bazı çağrışımlar yaratabildiğinden, ortada herhangi bir cümle olmaksızın, gene de, belli bir anlam bütünü elde edilebilmektedir (Başkan, 2006, s. 101). Her sözcüğün yüklendiği ve taşıdığı anlam farklı olduğu gibi herhangi bir sözcüğün gerçek anlamı yanında mecaz, yan vb. anlamları çerçevesinde anlam yelpazesi ve kullanım durumları da farklıdır. Dahası, bir sözcüğün kullanıldığı gerçek anlamının da cümle, paragraf ya da genel ifade ile kullanıldığı bağlam içerisinde anlam yüklenilebilmekte, anlam boyutunda değişiklik olabilmektedir (Göçer, 2014, s. 180).

Dile ait birtakım ifadelerle dil dışı nesneler arasında anlam bağlantısı gerçekleştiği kabul edilmektedir. Anlam bağlantısına giren ifadeler, yani 'anlam' taşıyan ifadeler kategoremarik ifadelerdir. Anlam bağlantısının genellikle her bir ifadeye karşılık bir tek 'anlam' belirleyebilmesi için iki yola başvurulabilir. Birincisi anlam bağlantısını bir somut ifade örneği ile dil dışı bir nesne arasında olan bir bağlantı şeklinde yorumlamaktır. Nitekim bir sözcük örneği, sözcüğün belli bir kimse tarafından belli bir zaman ve yerde, belli bir dilsel bağlam içinde kullanılması demektir. İkinci yola gelince; anlam bağlantısı somut bir ifade örneğine değil, ortak kullanıma uygun olarak soyut bir ifade tipine uygulanır. Ancak bir ifade tipinin genel olarak birkaç değişik anlamı olduğundan herhangi bir ifadenin anlamının 


\section{Türkçe Dersi Metin İşleme Sürecinde Bağlam Temelli Sözcük Öğretimi ve Etkin Sözcük Dağarcığı Oluşturmadaki İşlevi}

belirlenmesi için, kullanılışa ilişkin dil dışı durum (zaman, yer vb.) ile ifadenin kullanılışında içinde geçtiği dilsel bağlamla yorumlanabilir (Grünberg, 1970, s. 41-43).

Bir metni okumak, kolyedeki boncukları saymaktan ziyade, bu sürekli kırpışma sürecini izlemeye benzer. Bir cümleyi okurken cümlenin anlamı bir şekilde her zaman askıya alınır, ertelenir veya daha belli değildir, 'gelmekte'dir. Bir gösteren beni bir başkasına, o da bir başkasına götürür durur. İlk anlamlar sonraki anlamlar tarafından dönüştürülür ve cümle bitse de dil sürecinin kendisi bitmez. Her zaman orada olandan daha fazla anlam vardır. Bir cümlenin anlamını yalnızca kelimeleri mekanik bir biçimde üst este yığarak kavranamaz. Kelimelerin görece tutarlı bir anlam oluşturmaları için, her birinin, deyim yerindeyse daha öncekilerin izlerini taşıması ve kendini daha sonra gelecek olan kelimelerin izlerine açık tutması gerekir (Eagleton, 2004, s. 162). Bu durum okurun okunan metni anlaması, yeni anlamlar kurması ve çıkarımlarda bulunması, metindeki sözcükleri, sözcük dağarcığının verdiği imkânlar çerçevesinde düşünmeyip o sözcüklerin metnin bağlamında yüklendiği anlama odaklanmasına bağlıdır.

Sözcüklerin anlam yükünün farkından olmak, bir başka ifade ile bireyin sözcük dağarcığının zengin olması okunan metinden yapılabilecek alımlama ve çıkarımların en temel belirleyicisidir. Jean Paul Sartre'ye göre alımlama, eserin kendisinin kurucu bir boyutudur. Her edebi metin potansiyel okurlarını dikkate alarak inşa edilir (Eagleton, 2004, s. 111). Dil, simetrik gösteren ve gösterilen birimleri içeren, açık seçik sınırlandırımış, tanımlanmış bir yapıdan ziyade, barındırdığı unsurların sürekli bir karşılıklı ilişki ve dönüşüm içinde bulundukları, içindeki hiçbir unsurun mutlak olarak tanımlanamayacağı bir yapıdır. Yazarken iletmek istediğim anlamlar denetimden çıkma riskini taşır: düşüncelerimi yazı ortamı aracılığıyla ilettiğim ve basılı metnin kalıcı, maddi bir varlığı olduğu için, bu metin her zaman benim tahmin veya niyet etmediğim şekillerde dolaşıma sokulabilir, yeniden üretilebilir, alıntılanabilir, kullanılabilir. Bütün edebiyat metinleri başka edebiyat metinlerinden örülmüştür. Bu başka bir metinlerin 'etki'lerinin izlerini taşıdıkları gibi klasik bir anlama gelmez; her kelime, cümle ve kesitin eseri çevreleyen veya ondan önce yazılmış olan yazıların yeniden işlenmesi olduğu anlamına gelir (Eagleton, 2004, s. 163-164, 173).

Hirsch'e göre yazarın anlamı, kendine aittir ve okur tarafından çalınmamalı ya da ihlal edilmemelidir. Anlam, öldükten sonra bile onun üzerindeki münhasır haklarını koruyan yazara aittir. Gadamer ise, bir edebiyat eserinin anlamı hiçbir zaman yazarın niyetleriyle tüketilemez; eser bir kültürel veya tarihsel bağlamdan öbürüne geçtikçe ondan, yazarının veya yazıldığı döneminde yaşamış olan okurun düşünmediği yeni anlamlar çıkarılabilir (Eagleton, 2004, s. 94, 97). O zaman bir metnin okunması, anlamlandırılması, metinden yeni anlamlar kurulması ve çıkarımlarda bulunulmasında önemli olan okurun metne olan ilgisi, metinden beklentisi ve bilişsel alt yapısı büyük önem taşır. Metnin 
ne zaman, hangi kültürel ortamda ve nasıl bir tarihsel bağlamda yazıldığından çok, okurun sahip olduğu birikim ve bakış açısıyla hangi yelpazede çıkarımlarda bulunduğudur.

Edebiyatın var olabilmesi için okur da yazar kadar hayati önem taşır. Biz nasıl okuma stratejimizle metni değiştiriyorsak, metin de aynı zamanda bizi değiştirir. Metnin belirlenmişlikleri bizi onları yok edip yerlerine istikrarlı bir anlam kurmaya kışkırtır. Farklı okurlar eseri farklı şekillerde gerçekleştirmekte özgürdürler ve metnin semantik potansiyelini tüketecek tek bir doğru yorum yoktur. Ama bu cömertlik kesin bir talimatla sınırlandırılır: Okur metni içsel olarak tutarlı kılacak biçimde inşa etmelidir (Eagleton, 2004, s. 101, 106-109).

Gerek duygu ve düşüncelerin ifadesi ve okurlar için görünür kılınmasında gerekse ortaya konulan metinlerde üzerinde durulan unsurların anlaşılıp anlamlandırılmasında, hatta belirtilmeyen anlamların çıkarılmasında sahip olunan söz varlığının önem ve işlevi büyüktür.

Okuma algılama, belleğe kaydetme ve yeniden oluşturma/yapılandırma aşamalarıyla gerçekleşir. Metnin şifresini çözmeye girişen bir okuyucu, belli bir soyutlama ile anlam olgusuna ulaşır. Algılanan göstergeler zihinsel düzenleme, kavramlaştırma ve imgeleme ile anlam kazanır. Okuma tümcenin, paragrafın ya da metnin bitimine kadar bellekte tutarak ve bu bilgileri okuma eylemi boyunca öğrenilen yeni göstergelerle ilişkilendirerek bir arada algılama ve anlamlandırma sürecidir. Okumada yapılandırma, göstergeleri birbirleriyle ilişkilendirerek bir bakıma yorumlama işidir. Okuyucu okuduğunu anlamak ve bilgileri bellekte tutmak için değişik yöntemlerden yararlanır. Örneğin sözlük kullanır. Bilmediği sözcüklerin anlamını sözcüğün kullanıldığı bağlamdan çıkarmaya çalışır (Günay 2007a: 25-28).

Kelimenin anlam değerini belirleyen bütünün bağlam olduğunu belirten Onan (2012), bağlamın dil eğitimindeki anlam kurma süreçlerinde etkili olduğunun (s. 31); birbirinden ayrılmaz iki unsur olan sözcük anlamı ve bağlamın dilsel algılama sürecinde sözcüğün ya da cümlenin anlamsal işlevini bağlamın belirlediğinin altını çizmiştir (2011, s. 245). Bağlam kelimesinin Latince kökü, contexere'dir ve Türkçeye çevrildiğinde 'birlikte örmek' ya da 'parçalarıyla tutarlı olan' anlamını vermektedir. Bağlamın iki boyutu vardır: metinde ya da konuşmada ortaya çıkan dilsel bağlam ve olayın ya da konuşmanın geçtiği yer, zaman, kişi, sebep sonuç ilişkileri gibi unsurları içine alan yaşamsal -gerçek- bağlam. Kelime öğretiminde bağlam temelli yaklaşımın kullanılmasında; kelimelerin oluşturulan ya da bağlamlar içinde algılanması, anlaşılması, kullanılması ve hatırlanmasını sağlayarak öğretilmesi amaçlanır. Bu tekniğin sağlıklı bir şekilde uygulanabilmesi için, önceden belirlenmiş kelime listeleri ve bağlamların belirlenmiş olması tercih edilir. Örneğin, bahar teması altında öğretilecek isimler (kır, çiçek, gonca, tomurcuk, vb.), eylemler (çiçek açmak, tomurcuklanmak, uyanmak, vb.) gibi kelimeler listelenir. Bunların öğretimi için bir bağlam planlanır. Bu bağlam görsellerle ya da hikâyelerle oluşturulabileceği gibi, her ikisi de 


\section{Türkçe Dersi Metin İşleme Sürecinde Bağlam Temelli Sözcük Öğretimi ve Etkin Sözcük Dağarcığı Oluşturmadaki İşlevi}

kullanılarak oluşturulabilir. Bundan sonra kelimeler gerçek yaşamla ve bağlamla ilişkilendirilerek öğrenciye öğretilir (Gür, 2014, s. 245). Bağlam temelli kelime öğretimi, işlenen metin üzerinden ve öğrencilerin ilk kez karşılaştıklarını belirttikleri kelimelerin metinde yer ve işlevine göre de yapılır. Nation (1990, 2001) ve Read (2004), kelimelerin yazımları, üretiliş şekilleri, özellikleri, anlam özellikleri, bağlamsal ilişkileri gibi özelliklerle aktif ve pasif kelime dağarcığını geliştirme çalışmaları; kelime öğretiminde ve eğitim alanında daha çok ele alınmaya başladığını belirtmektedirler (Akt.: Gür, 2014, s. 244).

Bir kelimenin olduğu gibi, bir cümlenin, bir metnin veya bir eserin bağlamından söz edilebilir. Bir cümlenin de kesin olarak anlaşılabilmesi için metindeki cümleler arasındaki ilişkiden yola çıkılır; başka bir ifadeyle bağıntıdan hareket edilir (Aydın, 2007, s. 86). Günay’a (2007) göre bir metindeki bütünlük içinde, daha önce ve daha sonra aynı sözcük, izlek, kavram ya da düşünce aynı biçimde ya da farklı biçimde yeniden kullanılabilir. Her metinde, başka ögelere göre yorumlanabilecek artgönderimsel ve öngönderimsel birimler bulunur. Bu tür yapılar bağlamsal bir durumu ilgilendirir (s. 76).

\section{Ilköğretim Türkçe Programlarında Sözcük Öğretimi}

Amaçlar Başlığı Altında Kelime Öğretimi: Illköğretim Türkçe programlarında Türkçe öğretiminin amacı, Türk Millî Eğitiminin genel amaçları ve temel ilkelerine uygun olarak öğrencilerin;

'Türlü etkinliklerle öğrencilerin kelime dağarcığını zenginleştirmek, metinler arası düşünme becerilerini geliştirerek söz varlığını zenginleştirmek...' vb. amaçlara yer verilmektedir. İlköğretim Türkçe programlarında Kazanımlar başlığı altında sözcük öğretimi ile ilgili olarak verilen kazanımlar arasında şunlar sıralanmıştır:

Dinlediklerinde geçen bilmediği kelimelerin anlamlarını tahmin eder.

Dinledikleri kelimelerin gerçek ve mecaz anlamlarını ayırt eder.

Dinlediklerinde eş sesli, eş ve zıt anlamlı kelimeleri ayırt eder.

Bilmediği kelimelerin anlamlarını araştırır.

Kelimeleri doğru telaffuz eder, yerinde ve anlamlarına uygun kullanır.

Yazılarında söz varlığından yararlanır, kelime türlerini işlevine uygun kullanır.

Yazılarında sözlük ve imlâ kılavuzundan yararlanır, imlâ kurallarını uygular.

Görsellerden yararlanarak söz varlığını geliştirir.

Okuduğu cümledeki örtülü anlamları bulur.

Metinde ilk kez karşılaştığı kelime ve deyimleri sözlükten bulur.

Kelime listeleri, kavram haritaları kullanır, kelime türetir.

Terim, deyim, atasözü ve söz kalıplarını anlamlarına uygun olarak kullanır.

Metindeki kelimeleri, günlük hayattaki bağlamını dikkate alarak cümle içinde kullanır.

Dinlediklerinden/izlediklerinden hareketle yeni öğrendiği kelimelerden sözlük oluşturur.

Kelime oyunları oynar.

Dinlediklerindeki/izlediklerindeki anahtar kelimelerin farkına varır.

Dinlenenin/izlenenin bağlamından hareketle kavramların anlamlarını çıkarır.

Kelimeleri cümlede farklı görevlerde (isim, sıfat, zarf vb.) kullanır. 
Yeni öğrendiği kelime, kavram, atasözü ve deyimleri konuşma ve yazılarında kullanır... (MEB, 2005a: 135-139; MEB, 2005b: 134-149) vb. kazanımlar yer almaktadır.

Güneş (2013), kelime tanıma, kelime öğrenme ve zihinsel sözlüğü geliştirmede şu teknikler kullanıldığını belirtmektedir (s. 241-245):

Yeni kelimeleri tanıma: Metindeki yeni kelimeleri belirlemek için öğrencinin çeşitli ipuçlarından yararlanmayı bilmesi gerekir. Bunlar;
Anlam ipuçları
Ses-şekil ipuçları
Dil bilgisi ipuçları
Söz dizimi ipuçları
Sözlüksel ipuçları

Kelimelerin anlamını keşfetme: Bir metni okumadan önce bazı özel, anahtar kelimeler belirlenmelidir. Kelimelerin anlamlarını açıklığa kavuşturarak öğrenmek ve zihinsel sözlüğü zenginleştirmek için şunlar yapılır:

Bütünleştirme: öğrencilerin bilgileri ile yeni kelimeler arasında yeniden bağ kurma.

Işlevsel kullanma: yeni kelimelerin kullanılması sırasında öğrenciyi aktif kılmak ve kelimeyi basit bir tanımla geçiştirmek yerine, kelimeyi derinlemesine işlemek ve çeşitli cümlelerde kullanma.

Tekrarlama: Öğrencinin iyi anlaması ve bu işi seri biçime getirmesi için kelimeye benzer örnekler verme.

Kelimelerin anlamını metinden buma: Yeni kelimenin anlamını bulmak için metnin diğer kelimelerinden ve anlamından yararlanma tekniğidir.

Kavram haritası: kavram haritası, bir kavramı, onu oluşturan parçaları ve bunların birbirleriyle bağlantılarını gösterin bir görselleştirme tekniğidir.

Türkçe dersi öğrenme ve öğretme sürecinde sözcük öğretimi çalışmaları, çoğunlukla ve sistemli olarak metin işleme çalışmaları içerisinde gerçekleştirilmektedir.

Metin Işleme Sürecinde Sözcük Öğretimi

Metne Hazırlık Aşamasında Sözcük Öğretimi

Anahtar Kelimelerle Çalışma: Öğrencinin hem kavram gelişimini sağlamak hem de yeni öğrenilecek bilgiye ilgisini çekmektir. Bu açıdan, çalışma için seçilecek kelime ve kelime grupları metinle ilgili ipucu vermeli ve yeterli sayıda olmalıdır. Bu amaçla öğrencilere kelimenin çağrıştırdıkları kelimeresim eşleştirme vb. çalışmalar yaptırılmalıdır (MEB, 2005a: 161). 


\section{Türkçe Dersi Metin İşleme Sürecinde Bağlam Temelli Sözcük Öğretimi ve Etkin Sözcük Dağarcığı}

Oluşturmadaki İşlevi

\section{Okuma Anlama/Dinleme Anlama Aşamasında Sözcük Öğretimi}

Öğretim programında okuma anlama/dinleme anlama etkinlikleri içerisinde öğrencilerin sözcük dağarcıklarını öğrenme sürecinde geliştirmesi için birtakım kazanımlar sıralanmıştır. Bu kazanımlar arasında; 'Dinlediklerinde geçen bilmediği kelimelerin anlamlarını tahmin eder.', 'Metindeki kelimeleri, günlük hayattaki bağlamını dikkate alarak cümle içinde kullanır.', 'Metinde ilk kez karşılaştı̆̆ı kelime ve deyimleri sözlükten bulur.', 'Dinlediklerindeki/izlediklerindeki anahtar kelimelerin farkına varır.', 'Dinledikleriyle/izledikleriyle ilgili deyim ve atasözleri bulur.'

\section{Türkçe Derslerinde Sözcük Dağarcığını Geliştirme Uygulamaları}

Akyol ve Temur'a (2014) göre, anlamı bulmada 'kılavuzla keşfetme, bağlamsal tahmin ve sözlük kullanma' yöntemlerine başvurulabilir. 'Kılavuzla keşfetme (bulma)' yönteminde kelimenin anlamını bulmak için öğrencilere sorular sorulmakta veya örnekler verilmektedir. Bu çalışma, anlam ilişkilerinin kurulmasını zorunlu kıldığı için hem anlamı bulmaya hem de zihinde tutmaya katkı sağlamaktadır. 'Bağlamsal tahmin' kelimenin yer almış olduğu cümle ve paragrafın sağlamış olduğu ipuçlarından yararlanarak anlamın bulunmasıdır. 'Sözlük kullanma' ise bağımsız kelime öğrenme açısından gereklidir ve özellikle ortaokulda daha fazla önem kazanmaktadır (s. 205-206). Öğrencilerin sözcük dağarcığını geliştirmek amacıyla öğretmenler tarafından 1. bağlam (kontekst) ipuçlarından faydalanma, 2. sözlük kullanma ve 3. yapısal analiz yapma teknikleri kullanılabilir (Öztürk ve Otluoğlu, 2001 s. 47). Göçer'e (2009) göre, metin işleyişi sırasında ilk kez karşılaşılan ve anlamı bilinmeyen kelime tespit edildiği zaman öğretmen ne kendisi o kelimenin anlamanı açıklar ne de öğrencilerin sözlüğe başvurmalarına izin verir. Bu aşamada öğretmen; birtakım sorular sorarak öğrencilerin bilinmeyen kelimenin anlamını içinde bulunduğu cümlenin bağlamından çıkarmalarına ortam hazırlayabilir. Öğrencilere ipucu verir, varsa bağlam (kontekst) ipuçlarından faydalanma yoluna gidebilir. Bundan da bir sonuç alınamazsa sözlüğe bakmalarını söyler (s. 1037). Bu konuda Karatay (2007), sözcükler, anlamın küçük parçaları olduğundan onları sözlükteki anlamları ile öğrenmek yerine cümle içindeki anlamlarıyla öğretmenin daha faydalı olacağını belirtmektedir (s. 148).

Sözcük öğretiminde en önemli aşama üzerinde çalışılacak sözcüklerin seçimi ve seçilen sözcüklerin anlamının kullanılan bağlam içerisinden öğrencilerin çıkarmaları sürecidir. Metin işleme sürecinde üzerinde çalışılacak sözcükler, okuma anlama/dinleme anlama çalışmaları sırasında öğrencilerin ilk kez karşılaştıkları sözcükleri işaret ederek belirlemeleri şeklinde olmalıdır. Öğrencilere verilecek ipucu, yönerge ve yönlendirmelerle sözcüğün anlamını tahmin etmesine, cümledeki anlamı bulmasına veya keşfetmesine ortam hazırlanması önemlidir. Bu şekilde öğrenciler hem anlamı bulma sürecinde etkin olup dersi takip edecekler hem de süreçte işi yapan ve sonuca giden rolde oldukları için anlamı bulunan sözcüğü daha iyi kavrayacak, kalıcı ve kullanılabilir öğrenme ile sözcüğün ve anlamlarını 
zihinde yapılandırabilecektir. Bu konuda Yangın (2002) şunları söylemektedir: sözcük öğretiminde izlenebilecek yollardan biri buluş yoluyla öğretme stratejisidir. Bu stratejide şu yol izlenebilir. Sözcüğün anlamı doğrudan verilmez. Öğrencilere, sözcüğün temsil ettiği kavramın kendisi ya da resmi, varsa örnek olanları ve olmayanları sunulur. Öğrenciler bunları incelemek; bunlar üzerinde düşünmek için yönlendirilir. Bu süreç sonunda, öğrencileri kavramın belirgin özelliklerini bulmaları ve anlamı tanımaları sağlanır (s. 20).

Okuma ve dinleme metinlerinde anlama etkinlikleri sırasında ilk kez karşılaşılan kelimelerin öğrenimi çalışmaları

Okuma anlama ve dinleme anlama etkinliği sonrasında öğrencilerden yeni karşılaştıkları sözcükleri belirlemeleri istenir. Belirlenen sözcüklerin anlamının kavranılmasında ve öğreniminde şu aşamalar takip edilebilir:

\section{Anlamın metnin bağlamından/sözün gelişinden tahmin etme çalışması}

Sözcük dağarcı̆ııı zenginleştirme çalışmalarını sağlıklı bir biçimde yaptırmanın ilk adımı, öğrenciye sözcük kavramını ve sözcüğün anlam boyutlarını açık ve seçik bir biçimde kavratmadır. Sözcüklerin anlamını gerçekte içinde bulunduğu ögeler belirlemektedir. Sözcüklerin içinde bulunduğu, anlamlarını belirleyen ögelerin oluşturduğu bütüne yani sözcügün cümle içinde yerine bağlam denir. Sözcük çalışmalarında, öğrencilerin sözcük dağarcıklarını zenginleştirmede bağlam bizim için anahtar bir kavramdır (Özdemir, 1991, s. 215-217).

Okuma anlama/dinleme anlama aşamasında ilk kez karşılaştıklarını söyledikleri sözcüklerin anlamıyla ilgili olarak öğrencilere, sözcüğün içinde bulunduğu cümlenin anlam çerçevesinden hareketle sözcügün olabilecek anlamlarını tahmin etmeleri istenir.

\section{Bağlamından çıkarım yapmaya ipuçları verme}

Ediger, öğretilecek kelimelerin bağlam içerisinden çıkarıma dayalı olarak verilmesi gerektiğini vurgulamaktadır (2002: 5). Bağlam, bir dil birimini çevreleyen, ondan önce veya sonra gelen, onun anlamını, değerini belirleyen birim veya birimler bütünü, kontekst (TDK, 2005, s. 180), bir dil birimini çevreleyen, ondan önce ya da sonra gelen birçok durumda söz konusu birimi etkileyen, onun anlamını, değerini belirleyen birim ya da birimler bütünü (Vardar, 1998, s. 34) şeklinde açıklanmaktadır. Bir kelimenin anlamı bilinmiyorsa ve farklı bağlamlarda kullanılırsa o kelimenin kullanımıyla ilgili bir düşünce geliştirilebilir. Kelime daha önce görüldüyse ya da duyulduysa metin içinde cümlenin genel anlamı da düşünülerek kelimenin anlamı anlaşılabilir. Bunun için öğretmen de devreye girerek 


\section{Türkçe Dersi Metin İşleme Sürecinde Bağlam Temelli Sözcük Öğretimi ve Etkin Sözcük Dağarcığı Oluşturmadaki İşlevi}

öğrenciye ipuçları verebilir; ancak ipucu verme yöntemi her zaman öğrencinin anlamı doğru bileceğini kanıtlay(/n)amamıştır (Arı, 2013, s. 339).

Bağlam ipuçları, öğrencilere, bilmedikleri sözcüğün anlamını, bulunduğu yere göre çıkarma ve anlamlandırma olanağı verir. Yazarlar tarafından yazılı metinlerde sıkça kullanılan dokuz tür bağlam ipucu vardır. Bunların bilinmesi, sözcük dağarcığı ve kavram geliştirme süreçlerinde öğretmenlere yardımcı olabilir. Bu bağlam ipuçları şunlardır (Öztürk ve Otluoğlu, 2001, s. 47-48):

Betimsel Ipuçları: Cümledeki betimlemenin insan zihninde oluşturduğu tablo/resim, bilinmeyen sözcügün anlamını bulmaya yardımcı olur.

Sözlü Ipuçları: Bilinmeyen sözcükten önce veya sonra gelen cümleler olup onun anlamının bulunmasına yardımcı olurlar.

Yaşantı Ipuçları: Okuyucunun geçmişteki yaşantı ve gözlemleri, bilmediği sözcüğün anlamını bulmasina yarar.

Karşılaştırma ve Çelişki ipuçları: Iki sözcük birbirleriyle karşılaştırıldığında veya zıt anlamlar taşıdığında ortaya çıkar. Birisi yaygın, diğeri ise bilinmeyen sözcükler olabilir.

Eşanlamlı Sözcük Ipuçları: Bir cümlede aynı anlama gelen iki sözcük vardır. Bunlardan bilinen bilinmeyenin anlamının bulunmasını sağlar.

Özetleyici Sözcük Ipuçları: Bilinmeyen sözcük, bulunduğu cümlede -bazen kendinden önceki birçok cümlede-dile getirilen fikirlerin özetidir.

Tanım Ipuçları: Cümlede bilinmeyen sözcüğün doğru tanımı bulunmaktadır.

Kip ipuçları/Metnin Havası: Cümlenin ya da paragrafın genel havasının bilinmeyen sözcügün anlamını çağrıştırdığı ipuçlarıdır.

Bilinen Deyim Ipuçları: Bilinmeyen sözcük, bilinen bir deyim veya yaşantı içinde kullanılması hâlinde tanınır.

Flanigan (2012), bağlam ipuçlarının yaygın olarak dört başlıkla ortaya çıktığını açıklamaktadır ve öğrencilerden 'hangi bilginin kullanılır olduğu hangi bilginin kullanılır olmadığı hakkında düşünmelerini' istemektedir (Akt.: Yaman ve Akkaya, 2012, s. 2607):

Tanımlama-Tarif Etme Yoluyla: Kelime görünmekte olan cümle içinde, doğrudan ve net bir şekilde tanımlanmıştır.

Karşıtılk (Zıtılk) Yoluyla: Sıkıkla; oysa, rağmen, aksine, tersine gibi kelimelerle işaret verir.

Benzer (Yakın) Anlam Yoluyla: Cümle içindeki diğer kelimeler benzer anlamlarla kullanılır.

Çıkarsama (Sonuç Çıkarma) Yoluyla: Kelime anlamları doğrudan açıklanmaz, fakat bağlamdan hareketle çıkarsanması gerekir. 
Türkçe dersini işleyen öğretmenler, metin işleme süreçlerinde öğrencilerin ilk kez karşılaştıkları sözcüklerin bağlam içinde yer alma durumları yukarıdaki ipuçlarından birine uyuyorsa, bu durumu uygulayarak öğrencilerin kavram öğrenimine veya sözcük dağarcığının gelişimine uygun zemin oluşturabilirler.

\section{En son olarak sözcüğün anlamını sözlükten buldurma}

Metin işlenişi sırasında bilinmeyen bir kelimenin anlamını öğrenmede ilk iş olarak sözlüğe bakmak olmamalıdır. Kelimenin bağlamından ya da içinde bulunduğu cümlenin gelişinden anlamı çıkarılmaya çalışımalı, çıkarım yapılamadıysa öğretmen ipuçları vermeli, bu şekilde de öğrenci kelimenin anlamını çıkaramazsa sözlüğe başvurulmalıdır. Bu aşamada kelimenin sözlükte birden çok anlamı sıralanmışsa öğretmen öğrencilerine sözlükteki kaçıncı anlamın metindeki anlamla eşleştiğini sorar ve o anlamı farklı cümlelerde kullandırarak sözcüğün o anlamının kavranmasına ve kalıcı olarak öğrenilmesine çalışır (Göçer, 2009, s. 1037-1038).

Bütünleyici Çalışmalar: Metinde yer alan sözcükleri anonim ve seçkin edebî ürünlerle ilişkilendirerek bağlam içinde yüklendiği anlamı buldurma çalışmaları

Tekerlemeler, bilmeceler, fıkralar, masallar vb. dilin sunduğu seçkin edebî ürünlerdir. Bu edebî türler çocukların edebiyat dünyalarını oluşturur. Masalların dışında bilmeceler, fıkralar ve tekerlemeler çocuklar tarafından yeniden üretilebilir (Önal, 2002, s. 2). Bilmeceler, dilimizin tasarlamaya yatkın anlatım özelliğini, dil ve düşünce arasındaki güçlü ilişkiyi, Türkçe kelimelerin çok anlamlılığını yansıtan dilsel örneklerdir. Bilmecelerde çarpıcı benzetmeler ve ilginç buluşlar dikkat çekmektedir. Çocuklar için sözcüklerle üretilmiş bir oyun aracı olan bilmeceler, onlara düş ve düşünce gücüne seslenen kurmaca bir dünya sunar (Sever, 2008: 148). İkilemeleri, deyimleri, atasözlerini, duaları, bedduaları ve birbirinden güzel renkli, inceliklerle yüklü halk dili söylemlerini anlatım biçimlerinde barındıran masallar (Yavuz, 1997, s. 439), öğrencilere dilin inceliklerini gösterir, söz varlığını genişletir, anlama ve anlatma becerilerinin gelişmesine yardımcı olur (Göçer, 2009, s. 1044).

Edebî ürünlerde geçen deyimleri öğrenen öğrencilerin kelime dağarcığı ve anlam evreni genişler (Göçer, 2009, s. 1044). Deyimler, dilin kullanım süreçlerinde kelimelere farklı anlamlar yüklenerek oluşan yapılardır. Okunan ya da dinlenen metinlerde geçen deyimlerle ilgili olarak söz konusu deyimin ortaya çıkışı sürecinde oluşan öyküsü -varsa- anlatılarak öğrencilerden öyküden hareketle deyimin anlamını çıkarmaları istenebilir. 
Türkçe Dersi Metin İşleme Sürecinde Bağlam Temelli Sözcük Öğretimi ve Etkin Sözcük Dağarcığı Oluşturmadaki İşlevi

\section{Sonuç ve Öneriler}

Öğrencilerin kelime hazinelerinin geliştirilmesi önemlidir. Kelime hazinesinin zenginleştirilmesi ancak bir planlama ile mümkün olabilir (Karadağ ve Kurudayıoğlu, 2010, s. 435). Kelime öğretiminde en etkin yol bağlamdan harekettir. (McCarten, 2007, akt.: Güney ve Aytan, 2014, s. 621) Öğrenciler, bağlamda sözcüklerin çağrıştırdığı anlamları daha rahat görürler, üstelik anlama becerileri kamçılanır. Cümle ortamı sözcük dizgelerinden daha üstündür, çünkü cümle ortamında öğrenciler sözcüklerin anlamlarını bilmeden sözcüklerin cümle içinde geçişlerinden rahatlıkla çıkarabilirler (Demirezen, 1983, s. 164). Kelime öğretiminde, kelimenin -en az cümle bazında olmak üzere- belli bir bağlam içinde verilmesi, etkin bir şekilde öğretilmesi, kullandırılması gibi hususlara dikkat edilmesinin gerekliliği vurgulanmaktadır (Senemoğlu, 1983, akt.: Gürses, 2003, s. 512). Onan'a göre (2011), kelimenin içinde bulunduğu bağlam ve bağlamla ilişkili olarak, kelimenin anlam değerlerini ifade eden derinlik boyutu ve çağrışım önem kazanmaktadır. Bu duruma kelimelerin metinden hareketle, belirli bir bağlam içerisinde öğretilmesi gerekmektedir (s. 91).

Sözcükler, 'Kelimelerin kullanımını bir yapı içinde göstermek için verilen örnekler aracılığı ile öğrencilerin şiir, hikâye, roman gibi türlerle, Türkçenin inceliğini ve etkileyici güzelliğini tanımalarını sağlamak (Göçer, 2001, s. 400)' amacıyla kullanılabilir ve bu şekilde işlevini daha iyi yerine getirdiği söylenebilir. Bu açıdan öğrencilerin Türkçeyi güzel, etkin ve doğru kullanan yazarların farklı edebi türlerdeki ürünlerinin seçkin örneklerini öğrencilerle buluşturmanın ve okunmasını sağlamanın önemi büyüktür.

Sözcük dağarcığını geliştirmenin en etkili yolu, öğrencilerin temel dil becerilerini geliştirecek etkinliklere yönlendirilmesi; onların okuma, dinleme, konuşma ve yazma etkinlikleriyle aktif söz varlı̆̆ı oluşturma ve geliştirme çalışmaları içerisine sokulmasıdır.

Öğretilmek istenen sözcükler, metin içerisindeki üstlendiği görevine dikkat çekilerek, sözcüğün o metnin bağlamında yüklendiği anlamın ne olabileceğine dair öğrencileri bilişsel olarak bağlama yoğunlaştırarak vermenin kalıcı ve kullanılabilir sözcük öğrenimine katkı verdiği söylenebilir.

Türkçe ders ve çalışma kitaplarının tamamı, bağlamsal/kullanımsal bilgi kazandırmaya yönelik etkinliklerin tamamına yönelik olacak şekilde yeniden düzenlenmelidir. Ders kitaplarındaki metinlerin seçiminde pedagojik bağlamdan yararlanılmalı ve bağlam temelli kelime öğretimi etkinlikleri tüm beceri alanlarına yönelik olmalıdır (Okur ve Dağtaş, 2014, s. 77).

Ana dili öğretimi sürecinde ve yabancı dil öğretimi sürecinde, kelime/kelime grubu bağlamlarının kasıtlı olarak önceden güçlendirildiği bağlama dayalı etkinlikler yapılabilir (Yaman ve Akkaya, 2012, s. 2608). 
Metin işleme sürecinde öğrencilerin öğrendikleri yeni kelimeler, ders içi ve ders dışında gerçekleştirilecek bütünleyici çalışmalarla kalıcılığı sağlanmalı ve sonraki zamanlarda anlama ve anlatmada kullanılabilir aktif sözcük dağarcığı ya da işlek kelime kadrosu içinde yer alması sağlanmalıdır.

Öğrencilerin karşılaştıkları yeni sözcüklerin anlam yüklerini içinde bulunduğu bağlam içerisinden akıl yürüterek buldukları zaman, kalıcı ve kullanılabilir bir öğrenme gerçekleşmektedir. Bu açıdan öğretmenler, metin işleme sürecindeki sözcük öğretimi çalışmalarını bağlam temelli sözcük öğretimi anlayışıyla gerçekleştirmelidirler.

Metin işleme sürecinde anlamı buldurulan sözcükleri edebî ürünlerle ilişkilendirerek bağlam içinde yüklendiği anlamı buldurmaya yönelik sınıf içi ve sınıf dışı tamamlayıcı çalışmalara yer verilebilir.

\section{Kaynakça}

Aksan, D. (2007). Her Yönüyle Dil - Ana Çizgileriyle Dilbilim (1. Cilt, 4. Baskı). Ankara: Türk Dil Kurumu Yayınları.

Akyol, H. ve Temur, T. (2014). Kelime Hazinesinin Geliştirilmesi (ss. 193-229), ilköğretimde Türkçe

Öğretimi (Editörler: A. KIRKKILIÇ, H. AKYOL). Ankara: Pegem Akademi Yayınları.

Arı, G. (2013). Kelime Öğretimi (ss. 337-363), Yeni Öğretim Programına Göre Kuramdan Uygulamaya Türkçe Öğretimi (4. Baskı, Editör: Cemal YILDIZ). Ankara: Pegem Akademi.

Aydın, M. (2007). Dilbilim El Kitabı (2. Baskı). İstanbul 3F Yayınevi.

Banguoğlu, T. (1986). Türkçenin Grameri (2. Baskı). İstanbul Türk Tarih Kurumu Basımevi.

Başkan, Ö. (2006). Yabancı Dil Öğretimi: Ilkeler ve Çözümler. İstanbul: Multilingual Yayınevi.

Başoğlu, N.; Kaplan, T. ve Okur, A. (2014). İlköğretim Birinci Kademede Sözcük Öğretimi İle Illgili Çalışmaların İncelenmesi. Ana Dili Eğitimi Dergisi, 2(4), 50-65.

Budak, Y. (2000). Sözcük Öğretimi ve Sözlüğün İşlevi, Dil Dergisi, 92, 19-26.

Demirezen, M. (1983). Yabancı Dil Öğretiminde Yabancı Sözcüklerin Ruhbilimsel Sorunları. Türk Dili, 379-380, 160-166.

Dilidüzgün, Ş. (2014). Türkçe Öğretiminde Sözcük Öğretme Yöntemlerinin Yeterliliği. Adıyaman Üniversitesi Sosyal Bilimler Enstitüsü Dergisi, 7(17), 233-258.

Eagleton, T. (2004). Edebiyat Kuramı: Giriş (2. Baskı, Çeviren: Tuncay Birkan). İstanbul: Ayrıntı Yayınları.

Ediger, M. (2002). Vocabulary Development and the Curriculum. ERIC, ED473483.http://www.eric.ed.gov/ERICDocs/data/erıcdocs2sql/content_storage_01/000 0019b/80/1a/cc/c7.pdf (indirilme tarihi: 28.08.2009).

Göçer, A. (2001). Türk Dili ile Illgili Sözlüklere Genel Bir Bakış ve Günümüz Illköğretim Sözlükleri. Türk Dili, 598, 388-403.

Göçer, A. (2009). Türkçe Eğitiminde Öğrencilerin Söz Varlığını Geliştirme Etkinlikleri ve Sözlük Kullanımı. Turkish Studies, 4(4), 1025-1055.

Göçer, A. (2014). Öğretmen Rolleri, Öğrenci Etkililiği ve Eğitim Kazanımları Bakımından Türkçe Dersi Metin İşleme Süreci. Millî Eğitim, 204, 167-198.

Göğüş, B. (1978). Orta Dereceli Okullarımızda Türkçe ve Yazın Eğitimi. Ankara: Kadıoğlu Matbaası.

Grünberg, T. (1970). Anlam Kavramı Üzerine Bir Deneme. Ankara: Ankara Üniversitesi Dil ve TarihCoğrafya Fakültesi Yayınları. 
Türkçe Dersi Metin İşleme Sürecinde Bağlam Temelli Sözcük Öğretimi ve Etkin Sözcük Dağarcığı Oluşturmadaki İşlevi

Günay, D. (2007a). Metin Bilgisi (3. Baskı). İstanbul: Multilingual Yayınları.

Günay, D. (2007b). Sözcükbilime Giriş. İstanbul: Multilingual Yayınları.

Güneş, F. (2013). Türkçe Öğretimi: Yaklaşımlar ve Modeller. Ankara: Pegem Akademi Yayınları.

Güney, N. ve Aytan, T. (2014). Aktif Kelime Hazinesini Geliştirmeye Yönelik Bir Etkinlik Önerisi:

Tabu. Akademik Sosyal Araştırmalar Dergisi, 2(5), 617-628.

Gür, T. (2014). Bağlam Temelli Öğretimin İlkokul Üçüncü Sınıf Öğrencilerine Kelime Öğretiminde Kullanılması. Uluslararası Türk Eğitim Bilimleri Dergisi, 2(2), 242-253.

Gürses, R. (2003). Kelime Öğretimi Üzerine Genel Bir Değerlendirme. Türk Dili, 622, 506-516.

Karadağ, Ö. ve Kurudayıoğlu, M. (2010). 2005 Türkçe Programına Göre Hazırlanmış Illköğretim Birinci Kademe Türkçe Ders Kitaplarının Kelime Hazinesi. TÜBAR-Türklük Bilimi Araştırmaları, 27, 423-436.

Karakuş, i. (2000). Türkçe, Türk Dili ve Edebiyatı Öğretimi (Öğretmen El Kitabı). Ankara: Sistem Ofset Yayınları.

Karatay, H. (2007). Kelime Öğretimi. Gazi Eğitim Fakültesi Dergisi, 27(1), 141-153.

MEB (2005a). ilköğretim Türkçe Dersi Öğretim Programı ve Kılavuzu (1-5. Sınıflar). Ankara: Devlet Kitapları Müdürlüğü Basımevi.

MEB (2005ь). Ilköğretim Türkçe Dersi Öğretim Programı ve Kılavuzu (6, 7 ve 8. Sınıflar; Taslak Basım). Ankara: Devlet Kitapları Müdürlüğü Basımevi.

Mert, E. L. (2009). Anadili Eğitim ve Öğretim Sürecinde Sözvarlığı Belirleme Çalışmalarının Önemi ve 'Deyim' Kazandırmaya Yönelik Etkinlik Önerileri. Adıyaman Üniversitesi Sosyal Bilimler Enstitüsü Dergisi, 2(2), 83-93.

Okur, A. ve Dağtaş, A. (2014). Ortaokula Yönelik Kelime Öğretimi Çalışmaları. Ana Dili Eğitimi Dergisi, 2(4), 66-84.

Onan, B. (2011). Anlama Sürecinde Türkçenin Yapısal İşlevleri. Ankara: Nobel Akademik Yayıncılık.

Onan, B. (2012). Dil Eğitiminin Temel Kavramları. Ankara: Nobel Akademik Yayıncılık.

Önal, M. N. (2002). Türkçenin Eğitim ve Öğretiminde Oyun Tekerlemelerinin Yeri ve Önemi, Muğla Üniversitesi Sosyal Bilimler Enstitüsü Dergisi, 9, 1-17.

Özdemir, E. (1991). Söz Dağarcığının Geliştirilmesi (ss. 212-227), Türk Dili ve Edebiyatı Öğretimi (Editör: Bekir Özer). Eskişehir: Anadolu Üniversitesi Açıköğretim Fakültesi Yayınları.

Öztürk, C. ve Otluoğlu, R. (2001). Sosyal Bilgiler Öğretiminde Edebî Ürünler ve Yazılı Materyaller. Ankara: Pegem A Yayıncilık.

Pehlivan, A. (2003). Türkçe Kitaplarında Kelime Dağarcı̆ıııı Geliştirme Sorunu ve Çözüm Yolları. Dil Dergisi, 122, 84-94.

Sever, S. (2008). Çocuk ve Edebiyat. İzmir: Tudem Yayınları.

TDK (2005). Türkçe Sözlük (10. Baskı). Ankara: Türk Dil Kurumu Yayını.

Üçok, N. (1947). Genel Dilbilim (Lengüistik). Ankara: Ankara Üniversitesi Dil, Tarih-Coğrafya Fakültesi Yayınları.

Vardar, B. (1998). Açıklamalı Dilbilim Terimleri Sözlüğü (2. Baskı). İstanbul: ABC Kitabevi.

Yalçın, S. K. ve Özek, F. (2006). Söz Varlığııın Temel Dil Becerilerinin ve Akademik Disiplinlerin Kazanımına Olan Etkileri, Millî Eğitim, 171, 130-139.

Yaman, H. ve Akkaya, D. (2012). Dil Biliminin Kelime Öğretimine Açılan Kapısı: Bağlam Türleri. Turkish Studies - International Periodical For The Languages, Literature and History of Turkish or Turkic, 7(3), 2599-2610.

Yangın, B. (2002). Kuramdan Uygulamaya Türkçe Öğretimi. Ankara: Dersal Yayıncılık. 